\title{
KOMUNIKASI PADA PELATIHAN ADAPTASI PERUBAHAN IKLIM (PROGRAM PELATIHAN CDCCAA DI KECAMATAN PANGURAGAN KABUPATEN CIREBON)
}

\section{The Communication of Training on Climate Change Adaptation (CDCCAA Training Program in The Panguragan Subdistrict Cirebon Regency)} Afnida Shoffati Noorfajria ${ }^{1}$, Djuara P Lubis ${ }^{2}$, Resfa Fitri ${ }^{3}$

\author{
${ }^{1}$ Peneliti yunior Centras, Lembaga Penelitian dan Pengabdian Masyarakat IPB \\ ${ }^{2}$ Staf pengajar Program Studi Komunikasi Pembangunan Pertanian dan Perdesaan SPs IPB \\ ${ }^{3}$ Seksi Pengembangan Kelembagaan, Direktorat Pengelolaan Air Irigasi, Kementerian \\ Pertanian
}

e-mail: noorfajria@gmail.com

\begin{abstract}
Farmers have local wisdom passed down from generation to generation as a guide in farming activities. However, the existence of climate change makes them must be able to adapt to new agricultural patterns. They are required to know in advance the appropriate planting season in order to avoid crop failure later. Nonetheless, the farmers who are figure most susceptible to this problem are precisely not to have such knowledge. For these reasons the Ministry of Agriculture in collaboration with JICA (Japan International Cooperation Agency) create a training program that is devoted to improving the adaptability of farmers in the face of climate change named CDCCAA (Capacity Development for Climate Change Adaptation in Agriculture and Other Relevant Sectors). The present study was aimed to evaluate the factors that influence of the communications programs that are indicated by the farmers' knowledge about climate change, the attitude of farmers facing climate change and the farmers tendency to act after the training. Based on the survey of 50 trainees in the Panguragan Subdistrict Cirebon Regency, and SEM analysis it is known that the individual characteristics significantly influence the communication process CDCCAA training program, and cosmopolity factors have also significant influence on the behavior of farmers against the risk of climate change. In addition, the communication process not significantly influence with attitudes to climate change risk, and assessment of training rogram not significantly influence with communication process also.
\end{abstract}

Keywords: climate change, process of communication, adaptation

\section{PENDAHULUAN}

Perubahan iklim merupakan permasalahan global yang banyak dibahas saat ini. Perubahan iklim bukan saja merusak keseimbangan alam, dan berakibat pada bencana alam, erosi, kekeringan lahan dan sungai ataupun banjir yang semakin sering, perubahan iklim juga merupakan penyebab bertambahnya kemiskinan di Indonesia. Menurut Lal et al. 2013, perubahan iklim telah merubah berbagai sektor, terutama pertanian. Penguapan yang semakin banyak membuat curah hujan juga semakin meningkat yang dapat mengakibatkan banjir dan sekaligus menyebabkan kekeringan di tempat lain, hal tersebut pula yang merubah pola tanam serta keberhasilan panen para petani. Jika kondisi ini dibiarkan berlarut-larut dan kondisi alam semakin buruk, dan Indonesia akan mengalami rawan pangan. Setiap individu dituntut untuk dapat beradaptasi dan mempersiapkan diri untuk menghadapi bencana alam akibat perubahan iklim. Penelitian terbaru menunjukkan bahwa orang hanya akan mengubah sikap mereka terhadap hal yang ilmiah seperti perubahan iklim ketika pemahaman ilmiah dan informasi sudah secara luas dikomunikasikan (Boon 2013). Hal tersebut relevan dengan progam pemerintah, yaitu program CDCCAA (Capacity Development for Climate Change Adaptation in Agriculture and Other Relevant Sectors) yang ditujukan untuk mengkomunikasikan dampak perubahan iklim serta peningkatan kapasitas adaptif terutama pada sektor irigasi pada petani, karena dari beberapa dampak perubahan iklim, masalah 
ISSN 1693-3699 (Cetak)

ISSN 2442-410

pengairan pada lahan pertanian harus segera diatasi, dan Kabupaten Cirebon merupakan salah satu daerah lumbung padi di Jawa Barat, sehingga program tersebut merupakan kegiatan prioritas di Kabupaten Cirebon. Petani harus mengerti betapa pentingnya kegiatan mitigasi dan adaptasi, dan seberapa bahayanya perubahan iklim pada sektor pertanian, sehingga, jika petani sudah memiliki pengetahuan tersebut, diharapkan dapat merubah persepsi dan sikap petani terhadap perubahan iklim, sehingga ikut serta dalam kegiatan adaptasi.

Namun tidaklah mudah untuk mengkomunikasikan risiko dari perubahan iklim, karena informasi perubahan iklim adalah informasi yang tidak menentu, dalam artian, dapat terjadi kapan saja, bisa sangat cepat, maupun sangat lambat, sehingga dibutuhkan strategi komunikasi yang baik dalam menyampaikan pesannya. Dibutuhkan analisis komunikasi program, untuk melihat seberapa jauh pengetahuan, sikap petani, serta perubahan perilaku petani, serta tindakan apa yang dilakukan setelah mengikuti pelatihan dari materi yang sudah diberikan oleh penyuluh, dan seperti apa penyuluh mengemas pesan,untuk membentuk persepsi petani mengenai perubahan iklim, karena menurut Somerville dan Hassol (2011), komunikasi perubahan iklim yang efektif tidak harus berupa ceramah ataupun perkuliahan, namun sebuah percakapan dimana seseorang benar-benar meningkat rasa kepeduliannya. Wirth, et al. (2014) juga menyatakan bahwa komunikasi yang efektif pada perubahan iklim ditandai dengan meningkatnya kesadaran, meningkatnya pengetahuan, memotivasi untuk melakukan tindakan, sehingga pada penelitian ini juga akan dilihat apa tindakan yang akan dilakukan petani bersama pemerintah setelah adanya pelatihan tersebut untuk upaya meningkatkan hasil pertanian serta memperbaiki sistem irigasi meskipun terdapat ancaman bahaya dari perubahan iklim.
Secara umum, penelitian ini bertujuan untuk menganalisis bagaimana perilaku komunikasi pelatihan CDCCAA pada petani mempengaruhi perilaku terhadap risiko perubahan iklim. Adapun tujuan khusus penelitian ini adalah: 1) Mendeskripsikan perilaku komunikasi saat pelatihan program CDCCAA pada petani; 2) Menganalisis hubungan karakteristik individu dengan perilaku komunikasi saat pelatihan program CDCCAA; 3) Menganalisis hubungan perilaku komunikasi saat pelatihan program CDCCAA dengan penilaian pelatihan program; 4) Menganalisis hubungan perilaku terhadap risiko perubahan iklim pada pelatihan dengan perilaku komunikasi saat pelatihan program dan tingkat kekosmopolitan.

\section{KERANGKA BERPIKIR}

Isu lingkungan saat ini yang sedang disorot oleh seluruh dunia adalah perubahan iklim, namun meskipun sedang marak dibahas, menurut Mors et al. (2010) tingkat pengetahuan dan kepedulian masyarakat masih rendah. Dengan alasan tersebut, maka dibutuhkan komunikasi yang bertujuan agar tercipta kepedulian dan pengetahuan yang lebih terhadap isu tersebut. Berdasarkan pemikiran tersebut, maka secara skematis kerangka berpikir penelitian yang dilakukan dapat dilihat pada Gambar 1. 


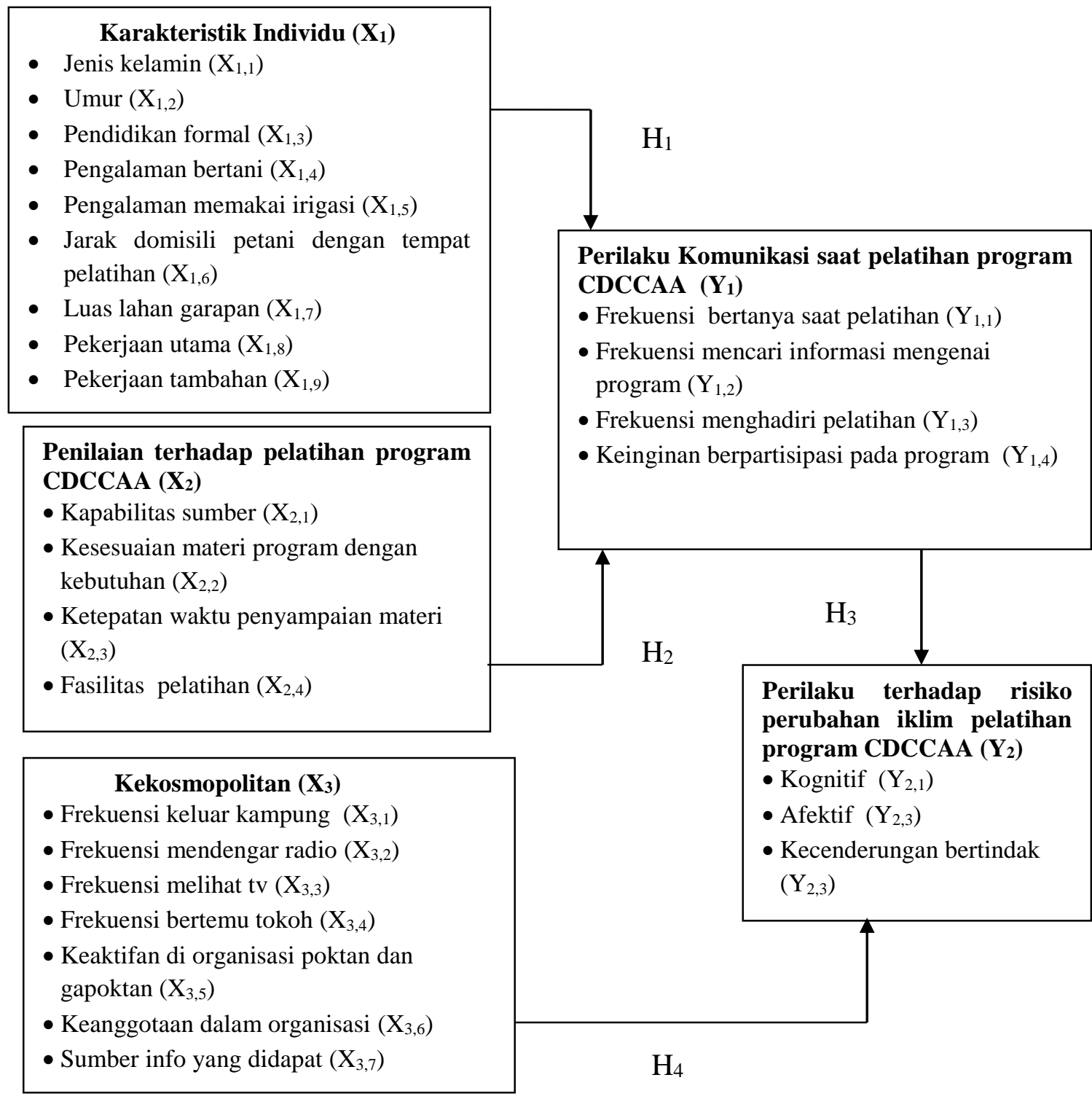

Gambar 1 Kerangka berpikir komunikasi pada pelatihan adaptasi perubahan iklim (program CDCCAA di Kecamatan Panguragan Kabupaten Cirebon)

\section{METODE PENELITIAN}

Penelitian dilaksanakan pada bulan Mei hingga Juni 2015 di Desa Panguragan dan Desa Kalianyar, Kecamatan Panguragan Kabupaten Cirebon Provinsi Jawa Barat. Lokasi penelitian dipilih karena daerah tersebut merupakan salah satu daerah lumbung padi di Jawa Barat, namun terdapat banyak jaringan irigasi yang rusak, sehingga daerah tersebut dipilih oleh Kementrian Pertanian dan JICA sebagai salah satu daerah yang akan

\section{dilaksanakan (Capacity}

Development for Climate Change Adaptation in Agriculture and Other Relevant Sectors). Selain hal tersebut, Kecamatan Panguragan merupakan kecamatan dengan permasalahan iklim yang cukup berdampak pada sektor pertanian. Pada saat musim hujan, kecamatan tersebut sering mengalami banjir, dan ketika musim kemarau, sering mengalami kekeringan. Populasi dari penelitian adalah seluruh peserta TOF 
(Training of Farmers) pada program tersebut di Kecamatan Panguragan, yaitu 50 peserta dengan pengambilan data dengan metode sensus. Data yang diambil merupakan data kuantitatif, yaitu dengan menggunakan kuesioner dan data kualitatif diperoleh dari catatan lapangan yang merupakan hasil wawancara terhadap beberapa responden dan pengamatan terhadap aktivitas responden pada saat pelatihan. Data yang didapat dari kuesioner kemudian dianalisis dengan menggunakan analisis SEM (Structural Equation Modeling) dengan menggunakan software SmartPLS (Partial Least Squares).

\section{HASIL DAN PEMBAHASAN Deskripsi Proses Pelatihan}

Pelatihan CDCCAA dilakukan selama 5 hari bertempat di BP3K (Balai Penyuluhan Pertanian, Perikanan dan Kehutanan) Kecamatan Panguragan, dengan 4 hari pelatihan di kelas dengan pemberian materi kepada peserta, diskusi peserta dan presentasi oleh peserta tiap kelompok (10 orang), dan 1 hari pelatihan di lapangan. Pada pelatihan di kelas, dalam satu hari, penyuluh memberikan dua materi sekaligus. Setelah materi disampaikan, peserta diminta untuk berdiskusi mengenai permasasalahan pertanian yang berkaitan dengan materi yang telah disampaikan dan hasil diskusi tersebut kemudian dipresentasikan. Materi yang disampaikan oleh penyuluh di kelas, merupakan materi yang berkaitan dengan adaptasi perubahan iklim pada sekor pertanian, antara lain: mitigasi, adaptasi dan antisipasi perubahan iklim, penguatan kelembagaan (khususnya P3A), konservasi sumber daya air dan pengelolaan jaringan irigasi, pengelolaan lahan, pengembangan agribisnis dengan penggunaan limbah cair organik, pertanian organik, pengendalian hama tikus dan pengenalan Trap Barier System (TBS). Pada kunjungan di lapangan, petani melihat langsung alat-alat yang mengukur unsur-unsur iklim di BMKG Jatiwangi di Majalengka dan peserta juga berdiskusi dengan petugas BMKG tentang hubungan iklim saat ini dengan pertanian. Kunjungan kedua, peserta melihat proyek pembuatan waduk Jati Gede, Sumedang. Air dari waduk tersebut nantinya akan mengaliri sawah pada daerah Jawa Barat, termasuk Kecamatan Panguragan, Kabupaten Cirebon, dimana pelatihan diadakan.

\section{Deskripsi Karakteristik Peserta Pelatihan \\ Dari variabel yang}

menggambarkan karakteristik peserta pelatihan, diketahui bahwa proporsi umur responden berkisar 23 hingga 65 tahun, dengan kisaran umur paling banyak adalah dewasa pertengahan (39 hingga 54 tahun), yaitu $46 \%$, menurut Dinas Kependudukan usia produktif adalah 15 hingga 64 tahun, dan responden paling banyak berumur 35 tahun sehingga dapat dikatakan usia responden sebagian besar adalah usia produktif. Pada jenis kelamin responden, peserta pelatihan didominasi oleh peserta laki-laki, yaitu $88 \%$, dan lainnya adalah peserta perempuan. Pemilihan proporsi peserta berdasarkan jenis kelamin ditentukan oleh penyuluh, hal tersebut dikarenakan pekerjaan petani lebih banyak dilakukan oleh laki-laki, dan perempuan biasanya tidak langsung mengolah sawah, melainkan pekerjaan lain yang berkaitan dengan pertanian, misalnya menjemur gabah. Pendidikan formal dapat mencerminkan pengetahuan dan perilaku seseorang. Menurut Rogers (2003), pendidikan juga akan mempengaruhi seseorang untuk menerima inovasi. Pendidikan formal responden paling banyak adalah pendidikan sekolah dasar saja (40\%), dan berdasar wawancara, ada beberapa orang yang tidak menyelesaikan pendidikan sekolah dasarnya, hanya beberapa tahun saja, kemudian putus sekolah karena harus bekerja dan tidak memiliki biaya untuk meneruskan pendidikan. Pengalaman bertani dan pengalaman memakai irigasi memiliki hasil yang hampir sama, rata-rata, 
ISSN 1693-3699 (Cetak)

ISSN 2442-410

responden memiliki pengalaman satu hingga sepuluh tahun. Hal tersebut juga berkaitan dengan umur responden didominasi oleh umur 35 tahun, sehingga pengalaman menjadi petani masih tidak begitu lama. Lamanya pengalaman bertani juga berkaitan dengan pekerjaan dari responden.

Dari kuesioner juga diketahui bahwa pekerjaan utama dari peserta tidak semuanya petani. Desa diadakan tempat pelatihan memang merupakan daerah pengumpul rongsok besi yang cukup besar, sehingga kebanyakan petani beralih profesi menjadi pengumpul rongsok dan menjadi pekerjaan yang lebih dominan dibanding menjadi petani, ditambah lagi dengan kondisi kekeringan sekarang ini, hal tersebut membuat petani mencari pekerjaan lain yang dapat menguntungkan.

\section{Deskripsi Perilaku Komunikasi Saat Pelatihan Program CDCCAA}

Perilakus komunikasi saat pelatihan program CDCCAA, dilihat dari seberapa banyak peserta bertanya pada saat pelatihan, banyaknya petani mencari tahu informasi sebelum pelatihan, motivasi apa yang membuat petani ingin mengikuti pelatihan tersebut, dan seberapa besar keinginan petani mengikuti pelatihan. Data hasil dari kuesioner menunjukan bahwa jumlah peserta paling banyak bertanya hanya 1 hingga 2 kali saja saat pelatihan, yaitu sebesar $58 \%$, jumlah peserta yang sering bertanya $24 \%$, sedangkan yang tidak bertanya sama sekali pada saat pelatihan hanya $18 \%$. Jumlah tersebut menunjukan antusias dari peserta yang besar dalam mengikuti pelatihan, dan hal tersebut juga didukung oleh jumlah banyaknya peserta yang mencari informasi sebelum diadakannya pelatihan, meskipun didominasi oleh peserta yang jarang mencari tahu, yaitu $40 \%$, namun jumlah tersebut lebih banyak dibanding dengan peserta yang tidak mencari informasi sama sekali $(36 \%)$. Pada motivasi dan besarnya keinginan juga menunjukan hasil yang sama besarnya. Seluruh peserta menjawab bahwa keinginan mereka untuk mengikuti pelatihan adalah benar-benar karena ingin mendapatkan ilmu dari pelatihan, dan besarnya keinginan untuk mengikuti pelatihan, seluruh peserta menjawab sangat ingin untuk mengikuti pelatihan tersebut. Hal ini dapat terjadi karena pelatihan yang akan disampaikan merupakan hal yang berkaitan langsung dengan petani dalam menangani lahan sawahnya yang sudah mulai tidak subur dan sering mengalami kekeringan.

\section{Penilaian Terhadap Pelatihan Program}

Penilaian terhadap pelatihan program dibagi menjadi dua bagian, yaitu penilaian terhadap pembicara pada saat pelatihan dan penilaian terhadap fasilitas yang ada pada pelatihan. Untuk penilaian pembicara, dari 10 pembicara, dipilih 3 pembicara yang paling mendominasi pada pelatihan. Hasil prosentase skor dari penilaian petani terhadap pembicara dan fasilitas secara keseluruhan didapat dari jumlah skor total dibagi dengan jumlah skor tertinggi (jika semua responden menjawab tingkat kesetujuan dengan skor 5, yaitu sangat setuju, maka prosentase skor bernilai 1, yang berarti setuju 100\%). Rata-rata responden menjawab pernyataan dengan jawaban setuju lebih dari 0.8 sehingga dapat dikatakan tingkat kesetujuan responden lebih dari $80 \%$. Dilihat dari penilaian pembicara, maka yang paling tinggi prosentase skornya adalah pembicara pertama. Akan tetapi prosentase skor pada pembicara kedua dan pembicara ketiga juga tidak jauh berbeda dengan pembica pertama. Hal tersebut membuktikan bahwa ketiga pembicara memiliki kredibilitas yang tinggi, sehingga para peserta memberikan penilaian yang baik.

"Pembicaranya enak, kalau bisa tiap tahun ada dan jadi agenda rutin, meskipun kadang-kadang ada yang membingungkan, ketika sudah siang dan 
ISSN 1693-3699 (Cetak)

ISSN 2442-410

capek, karena materinya banyak serta dipadatkan, sehari dua materi, dua diskusi, dua presentasi" (Peserta CDCCAA, 22 Mei 2015).

Untuk penilaian terhadap fasilitas, responden memberi nilai kesetujuannya sebesar $70 \%$. Hal tersebut sesuai pada saat pelatihan, ada beberapa fasilitas yang dirasa kurang memadai, contohnya adalah fasilitas ruangan. Fasilitas ruangan dirasa kurang karena terlalu sempit untuk menampung 50 peserta, sehingga peserta kurang dapat berkonsentrasi jika hari sudah menjelang siang, karena udaranya yang panas.

"Fasilitasnya sangat cukup, sayang ruangannya sempit kalau untuk 50 orang, jadi tidak nyaman rasanya" (Peserta CDCCAA, 24 Mei 2015).

\section{Kekosmopolitan Peserta Pelatihan}

Menurut Rogers (2003), seseorang yang cepat mengadopsi sebuah inovasi memiliki partisipasi sosial yang lebih dan memiliki jaringan sosial yang lebih banyak dibanding dengan seseorang yang mengadopsi inovasi secara lambat. Rogers juga menambahkan bahwa hubungan dengan agen perubahan (pada hal ini adalah penyuluh), serta keterdedahan media massa akan mempengaruhi seseorang mengadopsi suatu inovasi, dengan demikian kekosmopolitan responden perlu dianalisis untuk mengetahui apakah hal tersebut berhubungan atau mempengaruhi perilaku terhadap risiko perubahan iklim. Banyaknya responden keluar dari desa menunjukan bahwa kebanyakan responden sering keluar dari desa beberapa kali dalam satu bulan. Mereka mengaku, keluar desa untuk keperluan menjual hasil rongsok besinya ke kota, bahkan, untuk skala yang besar lagi, ada yang menjual hasil rongsoknya ke Jakarta, karena di Jakarta, hasil jualnya jauh lebih besar.
Jurnal Komunikasi Pembangunan

Untuk keterdedahan terhadap media massa, dipilih radio dan televisi sebagai indikatornya. Dari kuesioner, diketahui bahwa pendengar radio lebih sedikit dari penonton televisi, dan petani juga menonton televisi ketika malam saja, ketika setelah pulang dari sawah. Akan tetapi, pada responden pendengar radio, banyak yang mengatakan bahwa mereka sangat suka mendengar berita dari radio dibanding di televisi, karena dirasa lebih informatif, misalnya siaran pedesaan yang membahas mengenai pertanian di Kecamatan Panguragan, sehingga mereka lebih tahu, berita apa yang sedang ramai dibicarakan pada daerah mereka sendiri.

Responden juga sering bertemu dengan penyuluh, karena penyuluh pada daerah tersebut sering mengontrol sawah para petani pada wilayan binaannya, dan sering berinteraksi dengan petani lainnya pada pertemuan kelompok tani dan pengajian rutin. Dari kuesioner juga diketahui bahwa responden, kebanyakan mengetahui informasi perubahan iklim dari penyuluh, dan televisi, sebagian kecil dari radio dan hanya satu orang yang mendapat informasi perubahan iklim dari internet. Hal tersebut membuktikan bahwa penyuluh sangat berperan penting untuk menyebarkan informasi mengenai perubahan iklim.

\section{Perilaku Terhadap Risiko Perubahan Iklim}

Perilaku terhadap risiko perubahan iklim dapat dilihat dari kognitif, afektif dan kecenderungan bertindak. Dari segi kognitif, responden diberi 15 pertanyaan pilihan ganda, berkaitan dengan materi pada saat pelatihan, dengan demikian dapat diketahui sejauh mana pengetahuan dari responden mengenai pelatihan yang telah disampaikan. Pada afektif dan kecenderungan bertindak, peserta diberi pernyataan mengenai perubahan iklim dan rencana tindak lanjut dari program, kemudian responden diminta untuk menjawab sesuai dengan tingkat 
ISSN 1693-3699 (Cetak)

ISSN 2442-410

kesetujuannya pada pernyataan-pernyataan tersebut. Dari hasil jawaban responden mengenai kognitif, rata-rata nilai dari responden adalah 9.94. Jika dilihat dari rata-rata nilai tersebut, cukup jauh dari angka 15 (jumlah soal), sehingga dapat disimpulkan rata-rata pengetahuan responden tidak terlalu tinggi, namun, jika dilihat pada sebaran jawaban, jumlah terbanyak ada pada rentang 11 hingga 15 , yaitu sebanyak $46 \%$ responden.

Untuk hasil dari jawaban tingkat kesetujuan pada pernyataan afektif dan kecenderungan bertindak. Rata-rata responden menjawab pernyataan afektif dan kecenderungan bertindak dengan jawaban setuju sebesar lebih dari 0.8 (80\% setuju), prosentase skor tersebut didapat dari jumlah skor total dibagi dengan jumlah skor tertinggi (jika semua responden menjawab tingkat kesetujuan dengan skor 5, yaitu sangat setuju, maka prosentase skor bernilai 1, yang berarti setuju 100\%). Hal tersebut terbukti pada saat wawancara kepada responden, sebagian besar dari responden sudah melaksanakan rencana tindak lanjut, khususnya pada pembuatan pupuk organik cair.

Menurut responden, mereka sangat ingin mengikuti anjuran penyuluh pada saat pelatihan. Penyuluh sendiri sudah membicarakan rencana tindak lanjut tersebut, sayangnya pelatihan yang diadakan tidak sampai memfasilitasi rencana tindak lanjut tersebut, dan hanya membantu pembangunan saluran irigasi pada Desa Panguragan, sedangkan petani terkendala modal dan sumber daya manusia. Bahkan menurut penyuluh, jumlah petani sangat berkurang, karena banyak pemuda yang lebih senang bekerja di kota dan mengumpulkan barang rongsok untuk memenuhi kebutuhan hidupnya. Pada saat panen pada musim itu pun (bulan April hingga Mei 2015) sangat kekurangan tenaga kerja, panen menjadi terlambat, akibatnya banyak padi sudah terlanjur tidak bias dipanen, akibat lainnya adalah massa tanam kedua juga mundur, karena hal tersebutlah yang membuat rencana tindak lanjut dari pelatihan, tidak sepenuhnya dapat dilaksanakan sesegera mungkin, padahal sudah banyak kerugian yang dirasakan oleh petani karena adanya perubahan iklim.

"Rencana tindak lanjut sebenarnya sudah mau dilaksanakan, sudah ada kesiapan, tapi kurang tenaga kerja, banyak pemuda yang ke luar kota, ada juga yang jadi TKI ke luar negeri, dan bertepatan dengan panen raya, sehingga masih belum dapat dilaksanakan sepenuhnya" (Penyuluh BP3K Panguragan).

\section{Hubungan Antar Variabel}

Dari seluruh variable yang ada, setelah dianalisis dengan menggunakan metode SEM, terdapat nilai outer loading yang merupakan nilai kecermatan korelasi suatu variabel terhadap variabel lainnya. Agar model SEM memiliki kevalidan, maka outer loading harus lebih besar dari 0.5 , jika nilai outer loading kurang dari 0.5 , maka variabel tersebut akan deikeluarkan dari model. Untuk melihat outer loading yang paling mempengaruhi, dapat dilihat pada Tabel 1 dan Gambar 2. 
Tabel 1 Nilai outer loading komunikasi pada pelatihan adaptasi perubahan iklim (program pelatiha CDCCAA di Kecamatan Panguragan Kabupaten Cirebon)

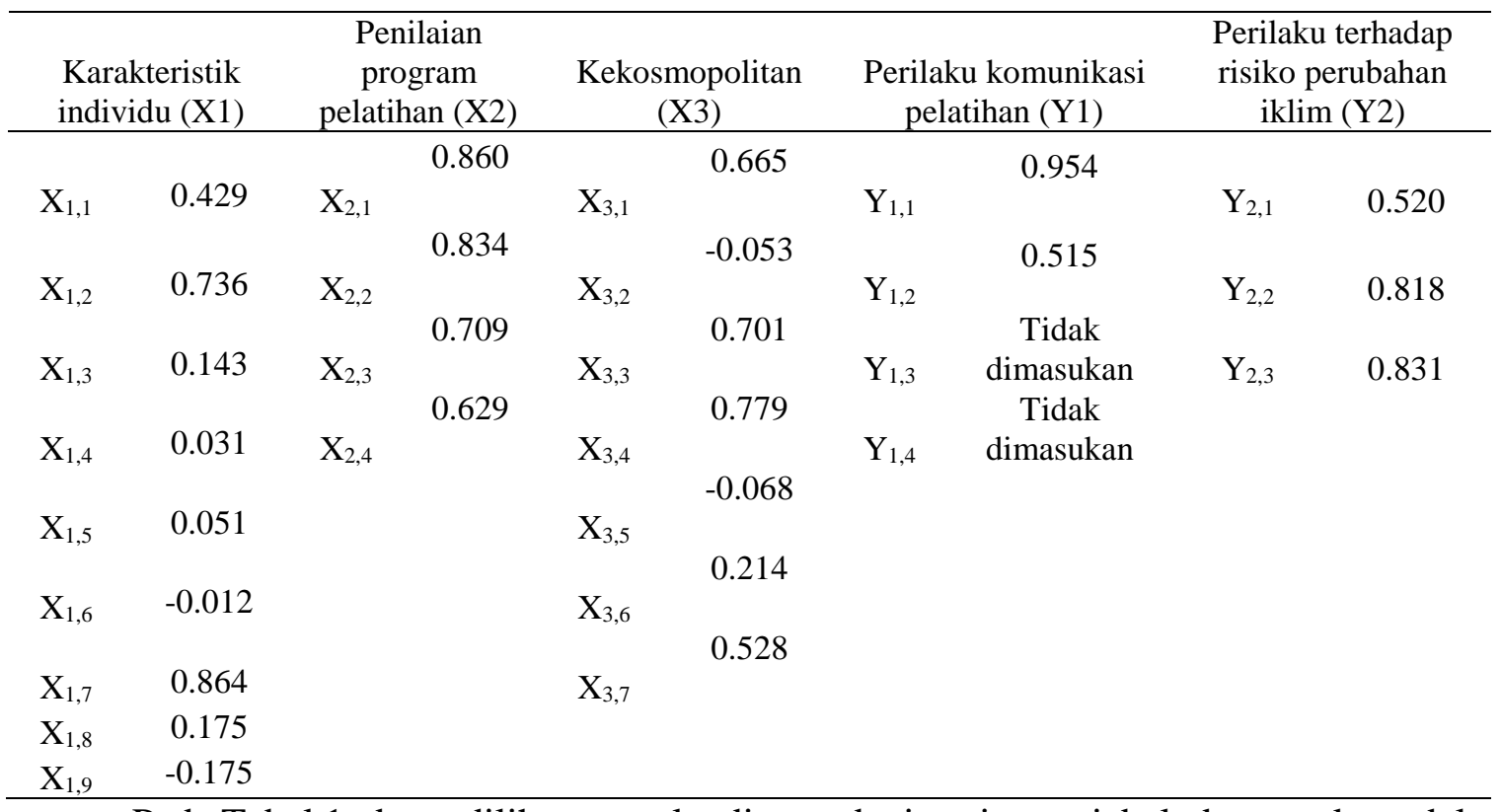

Pada Tabel 1, dapat dilihat outer loading pada tiap-tiap variabel, dan untuk model dari outer loading tersebut, dapat dilihat dari model PLS pada Gambar 2.

Gambar 2 Model PLS komunikasi pada pelatihan adaptasi perubahan iklim (program pelatiha CDCCAA di Kecamatan Panguragan Kabupaten Cirebon)

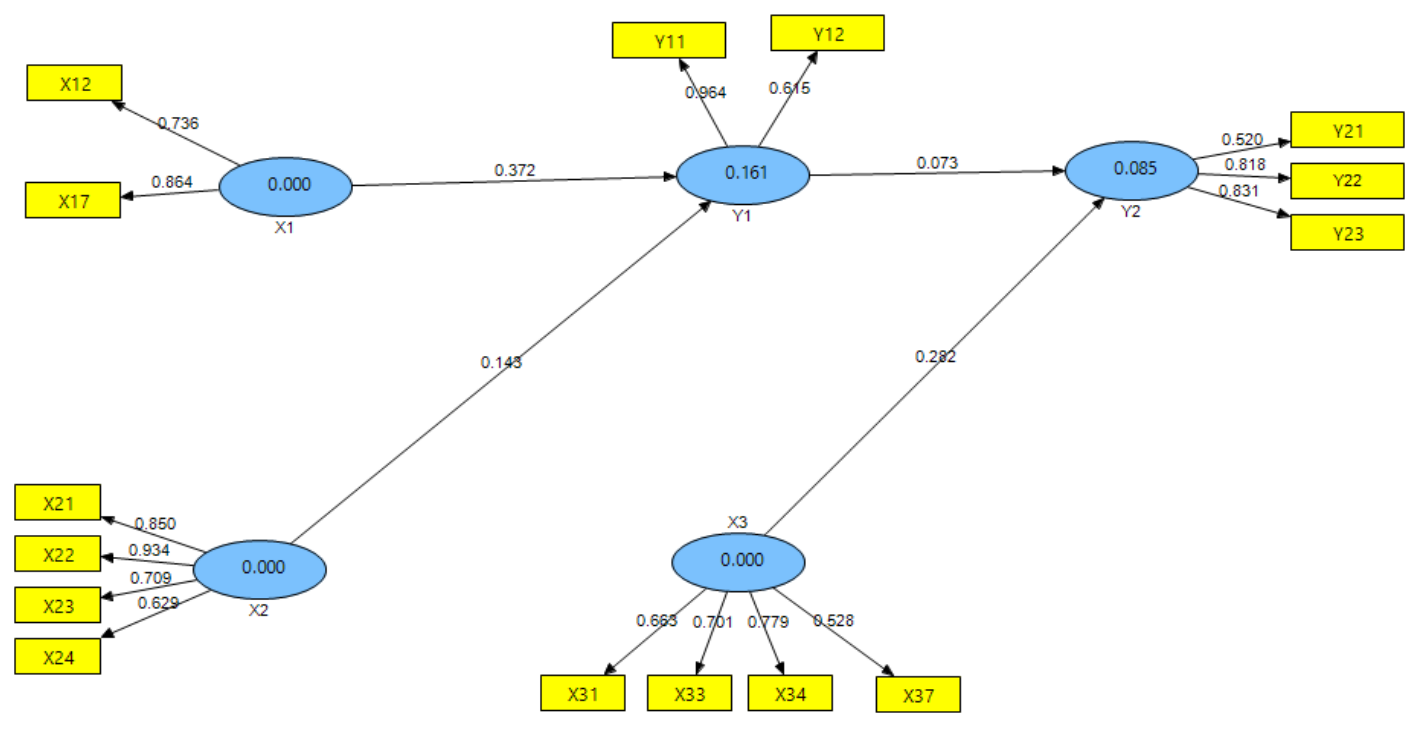


Setelah diketahui nilai koefisien korelasinya, maka untuk mengetahui signifikansi pengaruh (jika suatu variabel mempengaruhi variabel yang lain, maka sudah pasti terdapat hubungan pada antar variabel tersebut) maka dilakukan analisis bootsrap untuk mengetahui koefisien thitung. Model bootsrap dapat dilihat pada Gambar 3.

Gambar 3 Model bootsrap komunikasi pada pelatihan adaptasi perubahan iklim (program CDCCAA di Kecamatan Panguragan Kabupaten Cirebon)

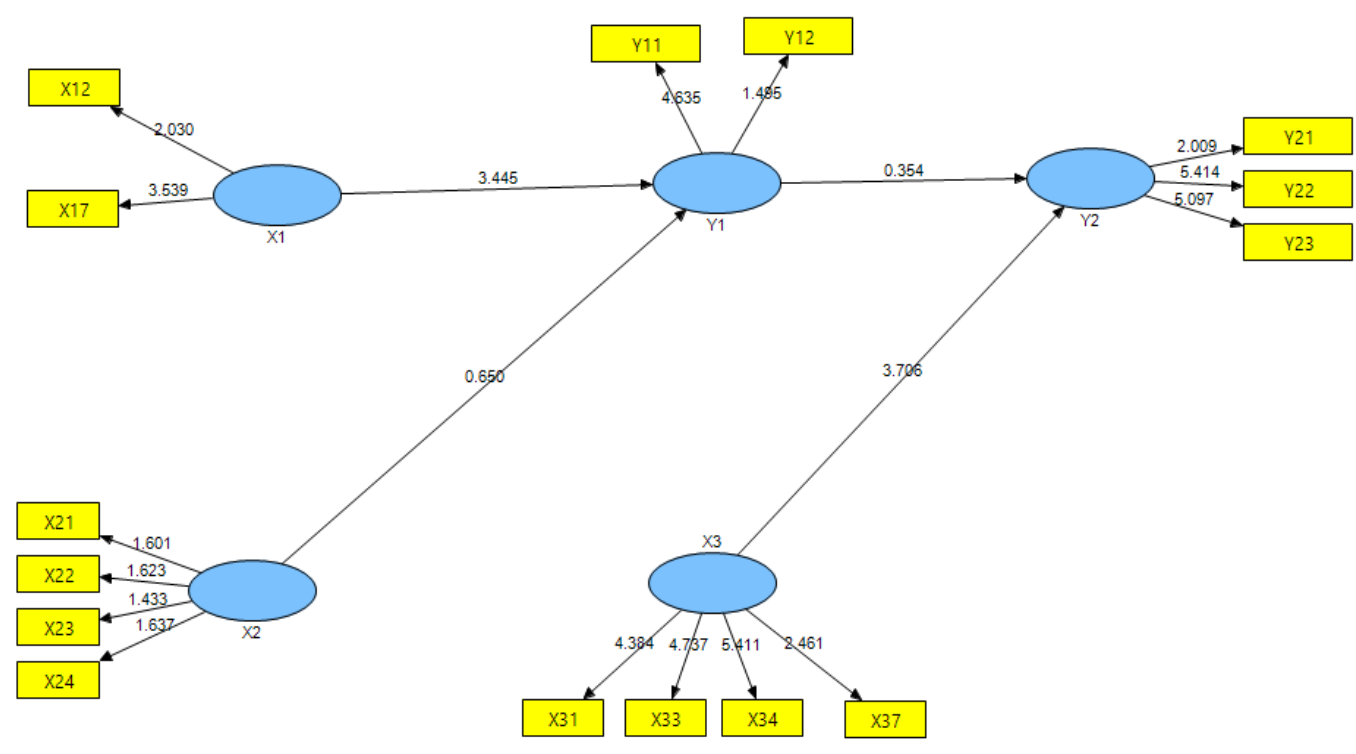

Gambar 3 merupakan model bootsrap, dan model tersebut menunjukan nilai $\mathrm{t}$ hitung dari tiap-tiap variabel terhadap variabel latennya, serta nilai $t$ hitung antar variabel, t hitung digunakan untuk melihat signifikansi dari pengaruh antar variabel. Untuk melihat perbandingan koefisien, $\mathrm{t}$ hitung dan keputusan signifikansi, dapat dilihat dari Tabel 2. 


\begin{tabular}{cccc}
\hline Uji koefisien & $\begin{array}{c}\text { Koefisien } \\
\text { korelasi }\end{array}$ & T-hitung & Keputusan $^{\mathrm{a}}$ \\
\hline $\begin{array}{c}\text { Karakteristik individu } \\
\text { (X1)---perilaku } \\
\text { komunikasi pelatihan } \\
\text { (Y1) }\end{array}$ & 0.372 & 3.445 & Signifikan berpengaruh \\
$\begin{array}{c}\text { Penilaian Pelatihan (X2)-- } \\
\text {-perilaku komunikasi } \\
\text { pelatihan (Y1) }\end{array}$ & 0.143 & 0.650 & Tidak signfiikan berpengaruh \\
$\begin{array}{c}\text { Kekosmopolitan(X3)--- } \\
\text { Perilaku terhadap } \\
\text { perubahan iklim (Y2) } \\
\text { Perilaku komunikasi } \\
\text { pelatihan (Y1)---Perilaku } \\
\text { terhadap perubahan iklim } \\
\text { (Y2) }\end{array}$ & 0.282 & 3.705 & Signifikan berpengaruh \\
\hline
\end{tabular}

Tabel 2 Nilai koefisien, nilai t hitung, keputusan signifikansi antar variabel

${ }^{\text {a }}$ Kaidah keputusan diukur pada t tabel $=1.96$ pada taraf uji 5\%, signifikan jika T-hitung > T-tabel

Pada Tabel 2, dapat dilihat nilai koefisien korelasi dan signifikasi antar variabel. Signifikan berpengaruh jika nilai t hitung lebih besar dari $t$ tabel (alpha5\%) yaitu1.96. Dari Tabel 2 dan Gambar 3 juga diketahui bahwa semua variabel berkorelasi positif dilihat pada model PLS yang menunjukan korelasi angka yang positif.

\section{Hubungan Proses Komunikasi Saat Pelatihan Program CDCCAA dengan Karakteristik Peserta Pelatihan}

Dilihat dari nilai outer loading (Gambar 2), indikator dari karakteristik individu yang paling berpengaruh terhadap proses komunikasi saat pelatihan program adalah umur dan luas lahan. Hal

ini dapat terjadi karena umur mempengaruhi kedewasaan dan pola berpikir seseorang serta pengalaman dalam melakukan usaha bertani, sehingga mempengaruhi proses komunikasi pada saat pelatihan, dibuktikan pada saat pelatihan, peserta yang banyak bertanya adalah peserta yang sudah berumur, sedangkan peserta yang masih dapat dikatakan dewasa muda agak pasif pada saat pelatihan. Luas lahan juga sangat berpengaruh pada proses komunikasi, karena semakin luas lahan yang dimiliki, maka semakin banyak responden mencari tahu dan bertanya pada saat pelatihan, sehingga banyak interaksi yang terjadi.

Dari analisis statistik dapat disimpulkan bahwa karakteristik responden signifikan berpengaruh terhadap proses komunikasi pada saat pelatihan (Tabel 2) dengan pengaruh yang positif artinya jika karakteristik responden naik maka komunikasi pada saat pelatihan akan naik. Hal tersebut didukung oleh penelitian Mors et al (2010) yang menyatakan bahwa tidak semua orang mengerti mengenai perubahan iklim maupun bagaimana cara mengatasinya, hal tersebut tergantung pada latar belakang yang melekat pada individu masing-masing, sehingga tidak semua orang dapat mengevaluasi informasi yang didapat dan memanfaatkannya.

Meskipun variabel karakteristik individu paling besar dijelaskan oleh variabel umur dan luas lahan, namun variabel yang lain juga ikut mempengaruhi proses komunikasi, meskipun korelasinya tidak banyak, hal ini dapat terjadi karena variabel yang lain memiliki nilai-nilai data yang homogen. 
Hubungan Perilaku Terhadap Risiko Perubahan Iklim Pelatihan Program CDCCAA dengan Kekosmopolitan

Diketahui dari analisis outer loading, indikator dari variabel kekosmopolitan yang paling mempengaruhi adalah adalah frekuensi keluar desa, frekuensi melihat televisi, frekuensi bertemu tokoh dan sumber informasi perubahan iklim (Gambar 2). Hal ini dapat terjadi karena jika seseorang keluar dari desa, lebih banyak menonton televisi, lebih sering bertemu tokoh dan lebih banyak mencari informasi perubahan iklim selain dari pelatihan, maka individu tersebut lebih terdedah oleh informasi, maka pengetahuan dan perilaku menghadapi perubahan iklim lebih dari individu yang lain. Dapat disimpulkan bahwa kekosmopolitan signifikan berpengaruh terhadap perilaku terhadap risiko perubahan iklim dengan pengaruh yang positif (Tabel 2).

Kekosmopolitan yang berpengaruh signifikan terhadap perilaku risiko perubahan iklim, sesuai dengan apa yang diungkapkan oleh Rogers (2003) yang menyatakan bahwa kekosmopolitan merupakan bagian dari perilaku berkomunikasi dari individu dan menurut Simanjuntak (2014) kekosmopolitan adalah keterbukaan seseorang pada informasi melalui kunjungan lainnya untuk mendapatkan berbagai sumber informasi, sehingga dapat dikatakan, semakin seseorang terdedah oleh informasi perubahan iklim, maka akan semakin mengerti bagaimana menyikapi adanya perubahan iklim tersebut.

\section{Hubungan Proses Komunikasi Saat Pelatihan Program CDCCAA Dengan Penilaian Terhadap Pelatihan Program}

Pada analisis SEM, didapat nilai outer loading (Gambar 2) memiliki nilai yang positif, dengan nilai outer loading terbesar ada pada penilaian kesesuaian materi $\left(\mathrm{X}_{2,2}\right)$, namun dari segi hubungan dengan proses komunikasi, penilaian terhadap program tidak signifikan berpengaruh, yaitu hanya sebesar 0.1414 .

Dari analisis keseluruhan, dapat disimpulkan bahwa jika penilaian program meningkat, maka proses komunikasi akan meningkat sebesar 0.1414 saja. Meski berpengaruh, namun hanya sedikit saja pengaruhnya, sehingga dapat dikatakan tidak signifikan. Hal tersebut dapat disebabkan penilaian responden kepada pembicara cenderung penilaian yang homogen, sehingga proses komunikasi tidak berubah secara signifikan. Pada proses komunikasi itu sendiri, jawaban responden untuk berpartisipasi pada pelatihan, memiliki jawaban yang sama, yaitu ingin memiliki ilmu dan tingkat keinginannya tinggi dalam mengikuti pelatihan, sehingga membuat hasil analisa tidak signifikan berpengaruh. Faktanya, berdasarkan wawancara, banyak petani menginginkan pelatihan diadakan lagi karena mereka membutuhkan ilmunya.

Penilaian dari peserta yang menyatakan kepuasan pada kemampuan penyuluh dalam menyampaikan informasi dapat mengindikasikan adanya perubahan sikap serta kecenderungan bertindak petani yang mendukung adanya kegiatan perubahan iklim, karena terdapat penelitian sebelumnya yang menyatakan bahwa ketidakpuasan seseorang akan penyampaian informasi akan berakibat pada gagalnya masyarakat untuk memahami sehingga tidak mempertimbangkan penggunaan informasi tersebut (Mors et al 2010).

\section{Hubungan Perilaku Terhadap Risiko Perubahan Iklim Pelatihan Program CDCCAA Dengan Proses Komunikasi Saat Pelatihan Program \\ Dengan melihat hasil dari outer loading pada Gambar 2, dapat disimpulkan bahwa varibel kecenderungan bertindak yang memiliki pengaruh paling tinggi. Pada analisa data dapat disimpulkan bahwa hubungan atau pengaruh proses}


ISSN 1693-3699 (Cetak)

ISSN 2442-410

komunikasi terhadap perilaku terhadap risiko perubahan iklim tidak terlalu signifikan, yaitu hanya sebesar 0.0733 (dikarenakan t-thitung lebih kecil dari 1.96 (t-tabel)). Dapat disimpulkan bahwa belum cukup bukti data untuk menyatakan hubungan signifikan antara proses komunikasi dengan perilaku terhadap perubahan iklim. Hal tersebut dapat terjadi karena responden memiliki banyak jawaban yang sama pada veriabel proses komunikasi, serta ada beberapa variabel dari proses komunikasi yang dihilangkan karena para peserta memiliki jawaban yang semuanya sama, yaitu pada frekuensi datang pada pelatihan dan motivasi peserta yang pada kenyataan di lapangan, seluruh peserta datang setiap hari dan tepat waktu pada jam yang telah ditentukan, serta memiliki motivasi yang sama, yaitu menginginkan ilmu dari pelatihan, sehingga tidak banyak mempengaruhi perilaku terhadap perubahan iklim. Kenyataannya di lapangan, responden memang memiliki semangat, serta keinginan yang tinggi dalam mengikuti pelatihan, dibuktikan dengan kehadiran penuh dan tidak ada yang terlambat, serta keaktivan ketika pelatihan, bahkan banyak rata-rata responden menyatakan keinginan untuk diadakan program lanjutan agar pelatihan tidak hanya sebatas teori di kelas.

\section{SIMPULAN DAN SARAN}

\section{Simpulan}

1. Perilaku komunikasi saat pelatihan program CDCCAA pada petani CDCCAA dapat dilihat dari interaksi petani dengan penyuluh maupun interaksi petani dengan petani lainnya. Rata-rata peserta jarang bertanya pada saat pelatihan, maupun pencarian informasi sebelum pelatihan diadakan, meskipun jarang bertanya, motivasi dan keinginan untuk mengikikuti program pelatihan tinggi, dibuktikan dengan peserta pelatihan yang tidak pernah absen dan selalu datang tepat waktu.
Jurnal Komunikasi Pembangunan

Juli 2015. Vol.13, No.2

2. Karakteristik individu berhubungan nyata dengan perilaku komunikasi pada pelatihan. Hal tersebut membuktikan bahwa karakteristik individu dapat membentuk kepribadian seseorang dan mempengaruhi pola berpikir seseorang.

3. Pada analisis penilaian pelatihan, data belum cukup bukti untuk menyatakan bahwa penilaian pelatihan berhubungan dengan proses komunikasi. Faktanya, responden memang menilai pelatihan dengan tingkat kesetujuan yang cukup tinggi, dan hal tersebut sesuai dengan tingkat keinginan responden yang juga tinggi untuk mengikuti pelatihan.

4. Semakin banyak seseorang memiliki interaksi dengan lingkungan luar dan semakin terdedah oleh media massa, maka akan mempengaruhi bagaima perilaku serta pengetahuan seseorang, dibuktikan pada analisis data, kekosmopolitan berpengaruh signifikan pada perilaku terhadap perubahan iklim.

5. Perilaku komunikasi pada pelatihan tidak berpengaruh secara signifikan terhadap perilaku terhadap perubahan iklim, meskipun belun dapat dikatakan berpengaruh signifikan, keadaan di lapangan menyatakan bahwa peserta yang aktif pada saat pelatihan ternyata sudah melakukan banyak perubahan pada sawahnya setelah diadakannya pelatihan.

\section{Saran}

1. Pemerintah perlu mengadakan pelatihan lanjutan untuk mengurangi dampak perubahan iklim pada pertanian agar petani dapat memiliki persepsi terhadap dampak perubahan iklim pada pertanian, bagaimana hal tersebut dapat terjadi serta bagaimana cara mencegahnya.

2. Dibutuhkan penelitian lebih lanjut untuk melihat kerentanan terhadap perubahan iklim dan kapasitas adaptif petani terutama petani pengakses irigasi 
ISSN 1693-3699 (Cetak)

ISSN 2442-410

yang diharapkan dapat memberikan saran terhadap program pelatihan selanjutnya.

3. Dibutuhkan pelitian lebih lanjut mengenai komunikasi risiko terhadap perubahan iklim dengan menambahkan beberapa variabel-variabel yang berkaitan dengan perilaku komunikasi antara komunikator dengan komunikan.

4. Saran untuk program pelatihan selanjutnya, penyuluh diharapkan lebih mampu menyampaikan pesan mengenai perubahan iklim pada petani, dengan lebih memperhatikan kebutuhan petani, sehingga petani dapat melaksanakan tindakan adaptasi sesuai dengan kebutuhan prioritasnya.

5. Program pelatihan juga sebaiknya dilanjutkan dengan program dengan praktik, sehingga tidak berhenti hanya sekedar teori di kelas dan dilupakan oleh peserta.

\section{DAFTAR PUSTAKA}

Boon H. 2013. Teachers and the communication of climate change science: a critical partnership in Australia. Di dalam: 5th World Conference on Educational Sciences WCES; 2013. Australia (AU). Procedia - Social and Behavioral Sciences 116. hlm 1006-1019.

Lal R. 2013. Food security in a changing climate. Ecohydrol \& Hydrobiol. 13:8-21.

Mors ET, Mieneke WHW, Naomi E, Dancker DLD. 2010. Effective communication about complex environmental issues: perceived quality of information about carbon dioxide capture and storage (CCS) depends on stakeholder collaboration. Environment Psychol. 30:347-357.

Rogers E. 2003. Diffusion of Innovation $5^{\text {th }}$ Edition. New York (US): Free Press
Jurnal Komunikasi Pembangunan

Juli 2015. Vol.13, No.2

Simanjuntak M. 2014. Tingkat keberdayaan dan strategi pemberdayaan konsumen [tesis]. Bogor (ID): Institut Pertanian Bogor.

Somerville RCJ, Hassol SJ. 2011. Communicating The Sience of Climate Change. [Internet]. Colorado (US): Climate Communication. hlm 48-53: [diunduh 2015 Mar 3]. Tersedia pada: http://www. climatecommunication.org.

Wirth V, Andrea P, Tosten G. 2014. Communicating climate change adaptation, state of the art and lessons from ten OECD countries. GAIA. 23(1): 30-39. 
ISSN 1693-3699 (Cetak)

Jurnal Komunikasi Pembangunan

ISSN 2442-410

Juli 2015. Vol.13, No.2 
ISSN 1693-3699 (Cetak)

Jurnal Komunikasi Pembangunan

ISSN 2442-410

Juli 2015. Vol.13, No.2 